JURNAL ILMU KESEHATAN BHAKTI HUSADA:

HeAlth SCIENCES JoURnAL, Vol. 11 No. 02, DeseMBER 2020

DOI: $10.34305 / j i k b h . v 11 i 2.185$
Ciptaan disebarluaskan di bawah

Lisensi Creative Commons Atribusi-

NonKomersial-BerbagiSerupa 4.0

Internasional.

\title{
EFEKTIVITAS HEALTHY DATES SEBAGAI SUPLEMEN KOREKSI PERTUMBUHAN BALITA STUNTING DI KOTA CIMAHI
}

\author{
Teguh Akbar Budiana, Dini Marlina \\ STIKes Jenderal Achmad Yani Cimahi \\ budianateguh@yahoo.co.id
}

\begin{abstract}
Abstrak
Stunting merupakan keadaan kekurangan gizi kronis pada masa pertumbuhan dan perkembangan sejak awal kehidupan, sehingga anak terlalu pendek untuk usianya. Kurma merupakan salah satu buah dengan kandungan gizi lengkap yang dapat diberikan untuk membantu memenuhi kebutuhan gizi. Tujuan: Mengetahui efektivitas Healthy Dates (sari kurma) sebagai suplemen koreksi pertumbuhan balita Stunting di Kota Cimahi.

Penelitian ini merupakan penelitian Kuasi eksperimen dengan desain random sampling pretest dan post test control group design. Total sampel sebanyak 40 balita stunting usia 24-59 bulan perbandingan 1:1 (20 Healthy Dates : 20 Multivitamin) dengan menggunakan purposive sampling, diberi $5 \mathrm{ml}$ setiap hari selama 3 bulan. Pendapatan dan pendidikan orang tua diambil menggunakan kuesioner,tinggi badan menggunakan microtoise, umur menggunakan bulan penuh, asupan zat gizi menggunakan recall 1x24 jam sebanyak 4 kali. Analisis menggunakan independent samples test, paired sample t-test, wilcoxon signed ranks test.

Pendapatan keluarga 75\% $\leq \mathrm{UMK}, 42.5 \%$ pendidikan ibu SMP, $37.5 \%$ pendidikan ayah SMA. Pada kelompok Healthy Dates rata-rata persentase asupan energy 54.12\%, protein $91.16 \%$, zink 56.09\%, kalsium $69.55 \%$. sedangkan kelompok multivitamin rata-rata persentase asupan energy $51.10 \%$, protein 91.32\%, zink 56.99\%, kalsium 77.10\%. Rerata Z-Score kelompok Healthy Dates sebelum perlakuan 2.62SD menjadi $-2.30 \mathrm{SD}$ ( $\mathrm{p}=0.001$ ), rerata Z-Score kelompok multivitamin sebelum perlakuan sebesar 2.46SD menjadi -2.15SD ( $\mathrm{p}=0.002$ ). Rerata Z-Score akhir pada kelompok Healthy Dates 0.32 \pm 0.17 , kelompok multivitamin $0.25 \pm 0.26(\mathrm{p}=0.147)$.

Pada kelompok Healthy Dates terdapat koreksi tinggi badan lebih besar dibanding multivitamin.
\end{abstract}

Kata kunci: Stunting, Healthy Dates, Kuasi Eksperiment 
JURNAL ILMU KESEHATAN BHAKTI HUSADA:

HeAlth SCIENCES JoURnAL, Vol. 11 No. 02, DeseMBER 2020

DOI: $10.34305 /$ jikbh.v11i2.185

\section{Pendahuluan}

Kejadian balita pendek atau biasa disebut dengan Stunting merupakan permasalahan gizi kronis yang dialami oleh balita di seluruh dunia. Pada tahun 2017 sekitar 150,8 juta balita di dunia mengalami stunting, lebih dari setengah balita stunting di dunia berasal dari Asia (55\%) sedangkan lebih dari sepertiganya (39\%) tinggal di Afrika (Kementrian Kesehatan, 2018). Prevalensi balita pendek di Indonesia cenderung fluktuatif, hasil Riskesdas tahun 2007 menunjukkan prevalensi balita pendek di Indonesia sebesar 36,8\%, meningkat menjadi 37,2\% tahun 2013. Meskipun tahun 2018 prevalensi Stunting di tingkat nasional menunjukkan penurunan sebesar $6,4 \%$ menjadi $30,8 \%$, namun angkanya masih jauh dari target Badan Kesehatan Dunia (WHO) yakni 20\% (Kementrian Kesehatan RI, 2018). Jawa Barat menurut riskesdas 2018 menyebutkan prevalensi stunting sebesar $31,1 \%$, sedangkan di Kota Cimahi sebesar 9,06\% (Dinas Kesehatan Kota Cimahi., 2019).

Stunting didefinisikan suatu kondisi balita yang memiliki panjang atau tinggi badan kurang berbanding umur. Kondisi ini diukur dengan panjang atau tinggi badan
Ciptaan disebarluaskan di bawah

Lisensi Creative Commons Atribusi-

NonKomersial-BerbagiSerupa 4.0

Internasional.

yang $\leq-2$ sampai -3 standar deviasi (Kementerian Kesehatan RI, 2020). Penyebab langsung terjadinya Stunting karena defisiensi zat gizi serta penyakit infeksi, sedangkan penyebab tidak langsung yakni ketahanan pangan keluarga, pola asuh dan pola makan keluarga, serta kesehatan lingkungan, dan pelayanan kesehatan. Sedangkan penyebab dasar terjadinya Stunting terdiri dari pendidikan, kemiskinan, sosial budaya, kebijakan pemerintah, dan politik (Trihono et al., 2015).

Stunting merupakan kondisi gagal tumbuh pada anak usia dibawah lima tahun (balita) akibat kekurangan gizi kronis dan infeksi berulang terutama pada periode 1000 Hari Pertama Kehidupan (HPK). Stunting dapat mengakibatkan balita mengalami gangguan tumbuh kembang, mengalami hambatan dalam perkembangan kognitif dan motorik, serta memiliki risiko yang lebih besar untuk menderita penyakit tidak menular seperti diabetes, obesitas, dan penyakit jantung pada saat dewasa (Bertalina \& Amelia, 2018). Asupan gizi dengan kualitas dan kuantitas yang baik sangat dibutuhkan terutama pada usia balita, karena balita berada pada masa E-ISSN 2623-1204 P-ISSN 2252-9462 | 138 
JURNAL ILMU KESEHATAN BHAKTI HUSADA:

HeAlth SCIENCES JoURnAL, Vol. 11 No. 02, DeseMBER 2020

DOI: $10.34305 /$ jikbh.v11i2.185

pertumbuhan dan perkembangan fisik serta kognitif dengan pesat. Asupan zat gizi yang dibutuhkan tubuh diperoleh dari zat gizi makro seperti energi, karbohidrat, protein dan lemak. Zat gizi makro merupakan zat gizi yang dibutuhkan dalam jumlah besar oleh tubuh dan sebagian besar berperan dalam penyediaan energy, pertumbuhan serta perkembangan. Sedangkan asupan zat gizi mikro dibutuhkan sedikit dalam tubuh namun fungsinya tidak bisa digantikan dengan zat gizi lain sehingga kebutuhannya harus tercukupi dalam makanan sehari-hari (Almatsier, 2010).

Keanekaragaman makanan akan menjamin ketersediaan berbagai macam zat gizi bagi tubuh untuk melaksanakan fungsinya yang juga merupakan salah satu cara memperbaiki kondisi Stunting. Pemberian makanan tambahan dapat membantu pemenuhan asupan zat gizi dalam jangka pendek, tanpa mengurangi konsumsi beraneka ragam makanan yang mengandung zat gizi seimbang setiap hari.

Kurma merupakan salah satu buah yang biasa dikonsumsi masyarakat. Buah kurma merupakan buah dari tanaman Phoenix dactylifera yang memiliki biji dengan satu lembaga. Kurma banyak
Ciptaan disebarluaskan di bawah

Lisensi Creative Commons Atribusi-

NonKomersial-BerbagiSerupa 4.0

Internasional.

mengandung karbohidrat, lemak, protein, berbagai mineral dan vitamin serta memiliki kandungan serat yang cukup tinggi (Marwat SK, Khan MA, Ahmad M, Zafar M, Khan MA, Fazal-ur-Rehman, 2009). Kurma dalam bahan makanan penukar dimasukkan dalam golongan kelima yakni golongan buah- buahan yang satu satuan penukar mengandung 50 kalori, 10 gram protein dan 12 gram karbohidrat (Almatsier, 2004). Sari kurma merupakan kurma yang dihaluskan dan diambil sarinya. Sari kurma ini berbentuk cair dengan konsistensi yang kental, berwarna hitam dan terasa sangat manis serta mengandung zat gizi yang lengkap seperti buah kurma. Penelitian ini bertujuan untuk menilai efektivitas Healthy Dates (sari kurma) dan multivitamin terhadap koreksi tinggi badan balita Stunting.

\section{Metode Penelitian}

Rancangan penelitian kuasi eksperimen dengan desain random sampling pretest dan post test control group design (1:1 matching umur dan jenis kelamin). Penelitian menggunakan dua kelompok yaitu kelompok Healthy Dates dan kelompok multivitamin, masingmasing diberi $5 \mathrm{ml}$ setiap hari selama 3 
JURNAL ILMU KESEHATAN BHAKTI HUSADA:

HeAlth SCIENCES JOURNAL, VOL. 11 No. 02, Desember 2020

DOI: $\underline{10.34305 / j i k b h . v 11 i 2.185}$

bulan. Sampel pada penelitian ini adalah balita usia 24 - 59 bulan yang dinyatakan stunting berdasarkan indeks TB/U (Tinggi Badan/Umur) berdasar hasil screening. Jumlah sampel yang digunakan sebanyak 20 balita Stunting pada kelompok Healthy Dates dan 20 balita Stunting pada kelompok multivitamin, sehingga total sampel sebanyak 40 balita Stunting, teknik pengambilan sampel menggunakan purposive sampling. Tahap pelaksanan diawali dengan izin penelitian, pengumpulan data primer menggunakan kriteria inklusi dan eksklusi, membagi responden dalam kelompok Healthy Dates dan kelompok multivitamin, pendapatan keluarga dan pendidikan orang tua diambil menggunakan kuesioner, pengukuran status gizi TB/U sebanyak 4 kali selama 3 bulan, recall 1x24 jam sebanyak 4 kali dan dianalisis dengan program Nutrisurvey.
Ciptaan disebarluaskan di bawah Lisensi Creative Commons Atribusi-

NonKomersial-BerbagiSerupa 4.0 Internasional.

Analisis data menggunakan Independent Samples Test untuk melihat perubahan rerata Z-Score akhir pada kelompok Healthy Dates dan multivitamin, paired sample t-test untuk melihat perbedaan $\mathrm{Z}$ score sebelum dan sesudah intervensi pada kelompok Healthy Dates dan wilcoxon signed ranks test untuk melihat perbedaan Z-score sebelum dan sesudah pada kelompok multivitamin. Penelitian ini telah mendapatkan persetujuan dari Komisi Etik Penelitian Kesehatan Sekolah Tinggi Ilmu Kesehatan Jenderal Achmad Yani Cimahi dengan Nomor: 01/KEPK/III/2020.

\section{Hasil}

Hasil penelitian didapatkan bahwa balita yang mengalami Stunting berada pada keluarga dengan berpenghasilan dibawah UMK Kota Cimahi yaitu sebesar Rp. 3.139.274,74 sebesar 75\%, dapat dilihat pada gambar 1 .

\section{Gambar 1 Pendapatan Keluarga Responden}

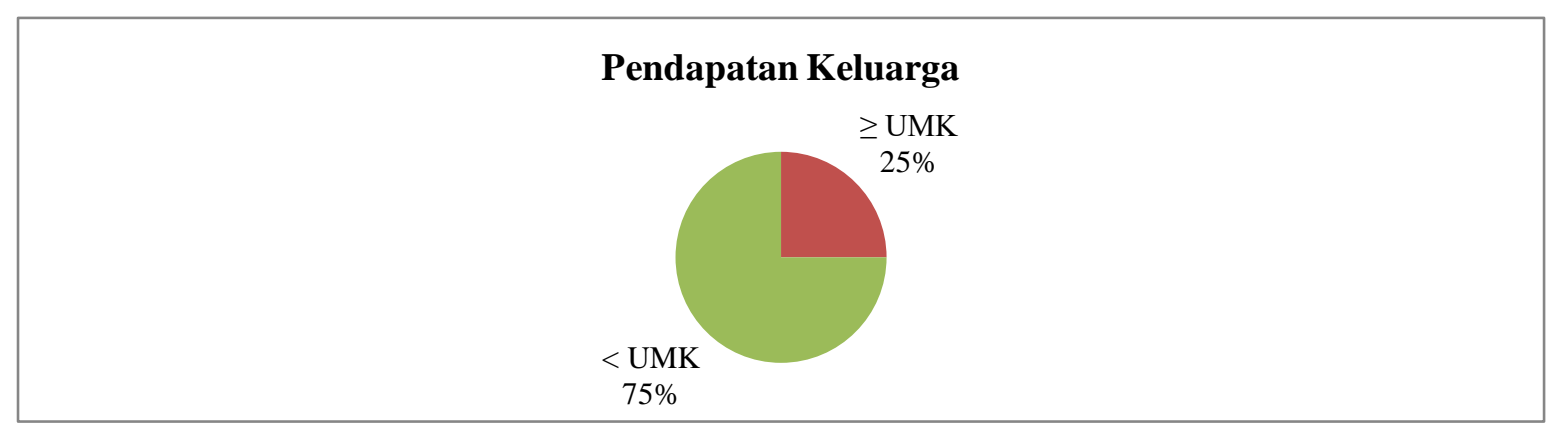


JURNAL ILMU KESEHATAN BHAKTI HUSADA:

HEALTH SCIENCES JoURnAL, Vol. 11 No. 02, DESEMBER 2020

DOI: $10.34305 / j i k b h . v 11 i 2.185$
Ciptaan disebarluaskan di bawah Lisensi Creative Commons Atribusi-

NonKomersial-BerbagiSerupa 4.0

Internasional.

Pada penelitian ini, pendidikan ibu balita Stunting sebanyak $42.5 \%$

berpendidikan SMP (sederajat), dapat dilihat pada gambar 2 .

\section{Gambar 2 Pendidikan Ibu Responden}

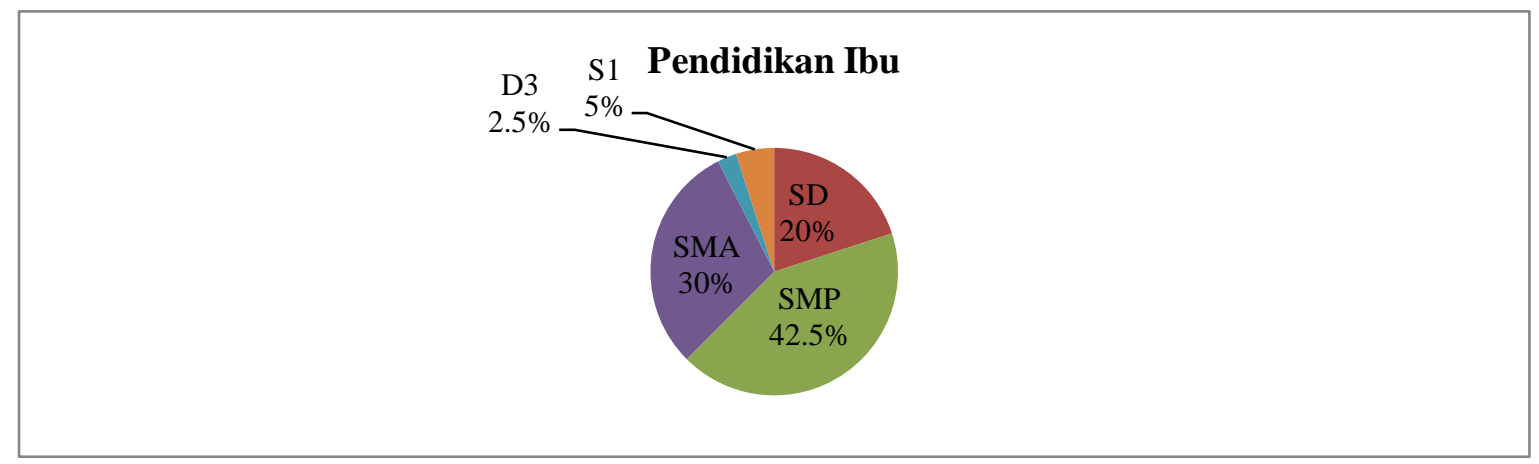

Pada penelitian ini, pendidikan ayah balita Stunting sebanyak

$37.5 \%$ berpendidikan SMA (sederajat), dapat

\section{Gambar 3 Pendidikan Ayah Responden}

2.5\%

Asupan zat gizi sangat penting dalam menunjang pertumbuhan dan perkembangan, adapun rata-rata dan dilihat pada gambar 3 . 
JURNAL ILMU KESEHATAN BHAKTI HUSADA:

HeAlth SCIENCES JoURnAL, Vol. 11 No. 02, DeseMBER 2020

DOI: $10.34305 / j i k b h . v 11 i 2.185$
Ciptaan disebarluaskan di bawah Lisensi Creative Commons Atribusi-

NonKomersial-BerbagiSerupa 4.0

\begin{tabular}{lllll}
\hline & Rata-rata & $\%$ & Rata-rata & $\%$ \\
\hline Energi (kkal) & 737.36 & 54.12 & 694.70 & 51.10 \\
& & & & 91.32 \\
\hline Protein (g) & 19.99 & 91.16 & 19.80 & 56.99
\end{tabular}

Kalsium (mg)

489.96

69.55

515.73

77.10

Pada tabel 1 diatas menunjukan dari 40 responden persentase angka kecukupan energi sebesar 54.12\% (defisit berat), kecukupan protein $91.32 \%$ (cukup), kecukupan Zink sebesar 56.99\% (defisit berat), dan kecukupan kalsium $77,1 \%$ (defisit sedang).

Tabel 2. Perubahan Z-Score Awal dan Akhir pada Kelompok Healthy Dates dan

\section{Multivitamin}

\begin{tabular}{lllllll}
\hline Variabel & \multicolumn{2}{l}{ Healthy Dates } & \multicolumn{2}{l}{ Multivitamin } & \multicolumn{2}{l}{ Selisih Z Score } \\
& \multicolumn{1}{l}{} & & & & \\
& Awal & Akhir & Awal & Akhir & HD & MV \\
\hline Z-Score & -2.62 & -2.30 & -2.66 & -2.41 & 0.32 & 0.25
\end{tabular}

Pada table 2 diatas menunjukan terdapat perubahan $\mathrm{Z}$-score menurut $\mathrm{TB} / \mathrm{U}$ sebelum dan sesudah perlakuan pada kelompok Healthy Dates dari -2.62SD menjadi -2.30SD terkoreksi 0.32SD, sedangkan pada kelompok multivitamin dari -2.66 SD menjadi $-2.41 \mathrm{SD}$ terkoreksi 0.25SD. Artinya baik pada kelompok Healthy Dates maupun multivitamin terdapat koreksi tinggi badan balita Stunting setelah mendapatkan intervensi selama 3 bulan.

Table 3. Perbedaan Z Score Sebelum dan Sesudah Intervensi Pada Kelompok Healthy Date 
JURNAL ILMU KESEHATAN BHAKTI HUSADA:

HeAlth SCIENCES JOURNAL, VOL. 11 No. 02, Desember 2020

DOI: $\underline{10.34305 / j i k b h . v 11 i 2.185}$
Ciptaan disebarluaskan di bawah Lisensi Creative Commons Atribusi-

NonKomersial-BerbagiSerupa 4.0

\begin{tabular}{llll}
\hline Healthy Dates & $\mathrm{N}$ & $\begin{array}{l}\text { Mean } \\
\text { (minimal-maksimal) }\end{array}$ & $\mathrm{P}$ \\
& & & \\
& & & \\
\hline Sebelum & 20 & $-2.62(-3.50--2.02)$ & \\
\hline Sesudah & 20 & $-2.30(-3.35--1.64)$ & \\
\hline
\end{tabular}

Pada tabel 3 diatas diketahui bahwa Hasil uji statistik menunjukkan data berdistribusi normal sehingga analisis uji beda memakai Paired sample t test untuk mengetahui perbedaan Z-Score sebelum dan setelah pemberian Healthy Dates

Table 4. Perbedaan Z-score Sebelum dan Sesudah Intervensi Pada Kelompok Multivitamin

\begin{tabular}{lccl}
\hline Multivitamin & $\mathrm{N}$ & $\begin{array}{c}\text { Median } \\
(\text { minimal-maksimal) }\end{array}$ & $\mathrm{P}$ \\
\hline Sebelum & 20 & $-2.46(-3.70--2.02)$ & 0.002 \\
\cline { 1 - 3 } Sesudah & 20 & $-2.15(-3.51--1.53)$ & \\
\hline
\end{tabular}

Pada tabel 4 diatas diketahui hasil

uji statistik menunjukkan data berdistribusi tidak normal sehingga analisis uji beda menggunakan Wilcoxon Signed Ranks Test untuk mengetahui perbedaan Z-Score sebelum dan setelah intervensi pada kelompok multivitamin. Rerata Z-Score selama 3 bulan. Rerata Z-Score sebelum perlakuan -2.62SD menjadi -2.30SD, hasil analisis didapatkan nilai $\mathrm{p}=0.001$ yang artinya terdapat perbedaan Z-Score sebelum dan sesudah diberikan Healthy Dates. sebelum intervensi sebesar $-2.46 \mathrm{SD}$ menjadi -2.15SD setelah diberikan multivitamin selama 3 bulan. Hasil analisis didapatkan nilai $\mathrm{p}=0.002$ yang artinya terdapat perbedaan Z-Score sebelum dan sesudah diberikan multivitamin.

Tabel 5. Perbedaan Z-score Sesudah Perlakuan Pada Kelompok Healthy Dates dan Multivitamin 
JURNAL ILMU KESEHATAN BHAKTI HUSADA:

HEALTH SCIENCES JoURnAL, Vol. 11 No. 02, DESEMBER 2020

DOI: $10.34305 / j i k b h . v 11 i 2.185$
Ciptaan disebarluaskan di bawah

Lisensi Creative Commons Atribusi-

NonKomersial-BerbagiSerupa 4.0

\begin{tabular}{llll} 
Kelompok & $\mathrm{N}$ & Mean $\pm \mathrm{SD}$ & $\mathrm{P}$ \\
\cline { 1 - 3 } Healthy Dates & 20 & $0.32 \pm 0.17$ & 0.147 \\
\cline { 1 - 2 } Multivitamin & 20 & $0.25 \pm 0.26$ & \\
\hline
\end{tabular}

Pada tabel 5 diketahui hasil uji statistik menunjukkan data berdistribusi normal sehingga analisis uji beda memakai Independent sample test untuk mengetahui perbedaan perubahan Z-Score setelah intervensi pada kelompok Healthy Dates dan kelompok multivitamin. Rerata Z-Score pada kelompok Healthy Dates terkoreksi 0.32SD selama 3 bulan, sedangkan pada kelompok multivitamin terkoreksi sebesar 0.25SD. Hasil analisis didapatkan nilai $\mathrm{p}=0.147$ yang artinya tidak terdapat perbedaan koreksi Z-score balita Stunting pada kelompok Healthy Dates dan kelompok multivitamin.

\section{Pembahasan}

Hasil penelitian menunjukan sebanyak $75 \%$ responden berasal dari keluarga yang berpendapatan di bawah UMK Kota Cimahi <Rp3.139.274(Surat Keputusan (SK) Gubernur Jawa Barat, 2019). Status ekonomi merupakan kedudukan seseorang atau keluarga di masyarakat berdasarkan pendapatan per bulan. Pendapatan yang tinggi akan meningkatkan peluang untuk membeli pangan yang kualitasnya lebih baik dan kuantitasnya lebih banyak. Sebaliknya, jika pendapatan keluarga rendah maka akan menurunkan kemampuan keluarga dalam menyediakan pangan dengan kualitas yang kurang baik dan kuantitas lebih sedikit(Astuti et al., 2017). Rumah tangga dengan tingkat pendapatan yang rendah tidak mampu menyiapkan makanan sesuai dengan kebutuhan, diantaranya tidak dapat membeli bahan makanan bergizi (Hoq et al., 2019). Selain itu mkanan yang di dapat akan kurang bervariasi dan sedikit jumlahnya terutama pada bahan pangan yang berfungsi dalam proses pertumbuhan seperti sumber energy, protein, vitamin, dan mineral, sehingga meningkatkan risiko terjadinya stunting (Wirjatmadi \& Adriani, 2012). Penelitian Illahi, (2017) menyatakan terdapat hubungan antara pendapatan keluarga dengan kejadian Stunting $\mathrm{p}=0.008$, begitu juga penelitian Chandra, (2013) 
JURNAL ILMU KESEHATAN BHAKTI HUSADA:

HeAlth SCIENCES Journal, Vol. 11 No. 02, DESEMBER 2020

DOI: $10.34305 /$ jikbh.v11i2.185

menyatakan bahwa pendapatan yang rendah merupakan faktor risiko kejadian Stunting pada balita. Pada penelitian ini kebanyakan orang tua responden yang pendapatan dibawah UMK bekerja sebagai buruh lepas harian, meskipun begitu kebutuhan akan zat gizi pada balita harus tetap terpenuhi karena balita sedang dalam masa pertumbuhan dan perkembangan yang cepat sehingga harus didukung dengan asupan zat gizi yang seimbang sesuai kebutuhan dan didapatkan dari makanan yang beranekaragam.

Tingkat pendidikan merupakan tahapan pendidikan yang ditetapkan berdasarkan tingkat perkembangan peserta didik, pada penelitian ini pendidikan ayah $37.5 \%$ SMA dan pendidikan ibu $42.5 \%$ SMP. Tingkat pendidikan ibu turut menentukan mudah tidaknya seorang ibu dalam menyerap dan memahami pengetahuan gizi yang didapatkan dan berhubungan terhadap kesehatan balita secara menyeluruh, hal ini disebabkan karena peran pengasuhan lebih besar dilakukan oleh ibu. Tingkat pendidikan yang lebih tinggi akan memudahkan seseorang atau masyarakat untuk menyerap informasi dan mengimplementasikannya dalam perilaku dan gaya hidup sehari-hari,
Ciptaan disebarluaskan di bawah Lisensi Creative Commons Atribusi-

NonKomersial-BerbagiSerupa 4.0 Internasional.

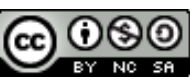

khususnya dalam hal pemilihan makanan yang bergizi (Suhardjo, 2007). Penelitian yang dilakukan Apriluana \& Fikawati, (2018), menyatakan terdapat hubungan antara faktor pendidikan ibu rendah memiliki pengaruh secara bermakna terhadap kejadian Stunting pada anak dan memiliki resiko mengalami Stunting sebanyak 1,67 kali, begitu juga penelitian yang dilakukan oleh Teguh A,. Susilowati, (2019), menunjukan terdapat hubungan antara pendidikan ibu dengan kejadian Stunting $\mathrm{p}=0.038$ dan memiliki resiko mengalami Stunting sebesar 4.7 kali.

Setelah diberikan multivitamin selama 3 bulan hasil analisis didapatkan nilai $(\mathrm{p}=0.002)$ yang artinya terdapat perbedaan Z-Score sebelum dan sesudah intervensi. Begitu juga pada kelompok Healthy Dates $(\mathrm{p}=0.001)$ yang artinya terdapat perbedaan Z-Score sebelum dan sesudah diberikan intervensi. Sedangkan untuk melihat efektifitas antara kelompok Healthy Dates dan kelompok multivitamin dilihat dari perbedaan rerata perubahan ZScore. Pada kelompok Healthy Dates nilai Z-Score terkoreksi sebesar 0.32SD, sedangkan pada kelompok multivitamin terkoreksi sebesar 0.25SD. Hasil analisis E-ISSN 2623-1204 P-ISSN 2252-9462 | 145 
JURNAL ILMU KESEHATAN BHAKTI HUSADA:

HeAlth SCIENCES JoURnAL, Vol. 11 No. 02, DeseMBER 2020

DOI: $10.34305 / j i k b h . v 11 i 2.185$

didapatkan nilai $\mathrm{p}=0.147$ yang artinya tidak terdapat perbedaan koreksi Z-score pada kelompok Healthy Dates dan multivitamin. Akan tetapi meskipun tidak terdapat perbedaan secara statistik, perubahan ZScore pada kelompok Healthy Dates lebih besar, hal ini dikarenakan kandungan zat gizi pada Healthy Dates lebih beragam. Healthy Dates kaya akan kandungan gula, protein dan banyak vitamin esensial. Healthy Dates yang diberikan berbentuk cair dengan konsistensi yang kental, berwarna hitam dan terasa manis serta mengandung zat gizi yang lengkap seperti buah kurma. Kandungan zat gizi pada Healthy Dates berfungsi untuk melengkapi asupan zat gizi dari makanan sehari-hari yang dapat mencegah terjadinya Stunting. Penelitian Fatmah, (2013) menunjukan pemberian biskuit tempe kurma dapat meningkatkan status gizi balita penderita tuberculosis sebesar $0,5 \mathrm{~kg}$ dan mengalami peningkatan rata-rata tinggi badan sebesar $1.7 \mathrm{~cm}$, begitu juga dengan penelitian Beriman et al., (2018) menunjukan ibu yang diberi sari kurma pada saat menyusui ASI eksklusif dapat meningkatkan status gizi bayi usia 0-5 bulan.

Energi dibutuhkan untuk
Ciptaan disebarluaskan di bawah

Lisensi Creative Commons Atribusi-

NonKomersial-BerbagiSerupa 4.0

Internasional.

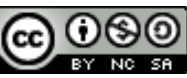

mendukung pertumbuhan, perkembangan, aktivitas otot, fungsi metabolik untuk memperbaiki jaringan rusak, untuk kelangsungan proses peredaran dan sirkulasi darah, denyut jantung, pernafasan, pencernaan dan proses fisiologis lainnya. Asupan energi yang tidak mencukupi kebutuhan, menyebabkan terjadinya ketidakseimbangan energi di dalam tubuh, apabila hal ini terjadi secara terus-menerus menyebabkan timbulnya masalah gizi seperti kekurangan energi kronis dan Stunting (Barasi, 2007). Pada penelitian ini asupan energi diperoleh dari hasil recall 1x24 jam sebanyak 4 kali, makanan sumber energy yang sering dikonsumsi oleh balita berasal dari nasi, dan olahan kacang kedelai. Hasil analisis menggunakan Nutrisurvey menunjukan angka kecukupan energi pada kelompok Healthy Dates sebesar 54.12\% (Defisit berat) dan pada kelompok multivitamin sebesar $51.10 \%$ (Defisit berat). Penelitian Ayuningtyas et al., (2018) menunjukan asupan energi berpengaruh terhadap kejadian Stunting pada balita, $(\mathrm{p}=0,001)$, begitu juga penelitian Anasiru \& Domili, (2019) yang menunjukan terdapat hubungan antara asupan energi dengan kejadian Stunting E-ISSN 2623-1204 P-ISSN 2252-9462 | 146 
JURNAL ILMU KESEHATAN BHAKTI HUSADA:

HeAlth SCIENCES JoURnAL, Vol. 11 No. 02, DeseMBER 2020

DOI: $10.34305 /$ jikbh.v11i2.185

$(\mathrm{p}=0,010)$.

Protein merupakan senyawa organik yang terdiri atas rantai panjang asam amino terikat satu sama lain dalam ikatan peptida. Bila tubuh mengandung cukup nitrogen, tubuh mampu mensintesis asam amino untuk pertumbuhan dan pemeliharaan jaringan (Almatsier, 2010). Asupan protein yang rendah menyebabkan tubuh tidak mengandung cukup nitrogen sehingga tidak dapat mensintesis asam amino untuk pertumbuhan, hal ini juga menyebabkan gangguan pada absorpsi dan transportasi zat gizi lain. Bila kejadian tersebut berlangsung lama maka dapat menyebabkan permasalahan gizi yang bisa memicu terjadinya stunting. Pada penelitian ini asupan protein diperoleh dari hasil recall 1x24 jam sebanyak 4 kali, makanan sumber protein yang sering dikonsumsi oleh balita terdiri dari telur, susu UHT, olahan kacang kedelai dan daging yang berasal dari unggas. Hasil analisis menggunakan Nutrisurvey angka kecukupan protein pada kelompok Healthy Dates sebesar 91.16\% (cukup) dan pada kelompok multivitamin sebesar $91.32 \%$ (cukup). Pertumbuhan dan perkembangan tubuh memerlukan asupan berbagai zat gizi yang seimbang baik makro
Ciptaan disebarluaskan di bawah

Lisensi Creative Commons Atribusi-

NonKomersial-BerbagiSerupa 4.0

Internasional.

maupun mikro nutrient. Pada penelitian kali ini meskipun asupan protein pada kategori cukup akan tetapi asupan energi dalam kategori defisit. Pada kondisi dimana intake energi dalam tubuh tidak tercukupi, akan terjadi pemecahan protein didalam tubuh sehingga fungsi yang seharusnya sebagai pertumbuhan dan zat pembangun dalam tubuh akan terganggu yang lama kelamaan akan menimbulkan permasalahan gizi salah satunya stunting (Almatsier, 2010). Penelitian yang dilakukan oleh Bertalina \& Amelia, (2018) menunjukan terdapat hubungan antara asupan protein dengan kejadian Stunting balita 6-59 bulan.

Zinc merupakan mikromineral yang terdapat dalam jaringan manusia dan terlibat dalam fungsi berbagai enzim dalam proses metabolisme. Zink diperlukan untuk aktivitas lebih dari 90 enzim yang ada hubungannya dengan metabolisme karbohidrat dan energi, degradasi/sintesis protein, sintesis asam nukleat, biosintesis heme, transport $\mathrm{CO} 2$ dan reaksi-reaksi lain (Maria C.L, 2010). Didalam Tubuh zink berinteraksi dengan hormon-hormon penting yang terlibat dalam pertumbuhan tulang seperti somatomedin-c, osteocalcin, testosterone, hormone thyroid dan insulin.

E-ISSN 2623-1204 P-ISSN 2252-9462 | 147 
JURNAL ILMU KESEHATAN BHAKTI HUSADA:

HeAlth SCIENCES JoURnAL, Vol. 11 No. 02, DeseMBER 2020

DOI: $10.34305 /$ jikbh.v11i2.185

Kadar zink yang sangat tinggi di tulang dibanding dengan jaringan lain ini sangat penting dalam memperkuat matriks tulang. Zink juga berfungsi memperlancar efek vitamin D terhadap metabolisme tulang melalui stimulasi sintesis DNA di sel-sel tulang. Oleh karena itu, zink sangat erat kaitannya dengan metabolisme tulang, sehingga zink berperan secara positif pada pertumbuhan dan perkembangan dan sangat penting dalam tahap-tahap pertumbuhan dan perkembangan (Almatsier, 2010). Pada penelitian ini asupan Zink diperoleh dari hasil recall 1x24 jam sebanyak 4 kali, makanan sumber Zink yang sering dikonsumsi oleh balita terdiri dari telur, susu UHT, olahan kacang kedelai dan daging-dagingan. Hasil analisis menggunakan Nutrisurvey angka kecukupan zink pada kelompok Healthy Dates sebesar $56.09 \%$ (Defisit berat) dan pada kelompok multivitamin sebesar $56.99 \%$ (Devisit berat). Penelitian Teguh A,. Susilowati, (2019) menyatakan bahwa defisiensi asupan zink berpengaruh terhadap kejadian Stunting pada balita (p value $=0,001$ )

Kalsium merupakan mineral yang paling banyak terdapat di dalam tubuh
Ciptaan disebarluaskan di bawah

Lisensi Creative Commons Atribusi-

NonKomersial-BerbagiSerupa 4.0

Internasional.

sekitar $1,5 \%$ - 2\% dari berat badan orang dewasa atau kurang lebih sebanyak $1 \mathrm{~kg}$, dari jumlah ini $99 \%$ berada di dalam jaringan keras, yaitu tulang dan gigi terutama dalam bentuk hidroksiapatit. Densitas tulang berbeda menurut umur, dan meningkat pada bagian pertama kehidupan lalu menurun secara berangsur setelah dewasa, selebihnya kalsium tersebar luas di dalam tubuh. Di dalam cairan ekstraseluler dan intraseluler kalsium memegang peranan penting dalam mengatur fungsi sel, seperti untuk transmisi saraf, kontraksi otot, penggumpalan darah dan menjaga permeabilitas membran sel. Fungsi lain dari kalsium antara lain sebagai bahan pembentukan tulang dan gigi, kalsium dan mineral lain memberi kekuatan dan bentuk pada tulang dan gigi. Kalsium di dalam tulang mempunyai dua fungsi, pertama sebagai bagian integral dari struktur tulang dan kedua sebagai tempat menyimpan kalsium (Almatsier, 2010). Fungsi utama dari kalsium dalam tubuh yaitu untuk pembentukan tulang dan gigi, dimana kalsium yang cukup dapat mempengaruhi kekutan tulang dan dapat membantu tulang tumbuh sesuai dengan fungsinya. Balita yang mengalami kekurangan kalsium

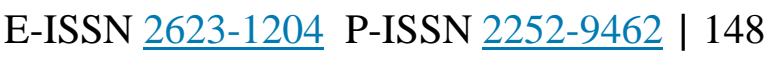


JURNAL ILMU KESEHATAN BHAKTI HUSADA:

HEALTH SCIENCES JoURnAL, Vol. 11 No. 02, DESEMBER 2020

DOI: $10.34305 / j i k b h . v 11 i 2.185$
Ciptaan disebarluaskan di bawah

Lisensi Creative Commons Atribusi-

NonKomersial-BerbagiSerupa 4.0

Internasional.

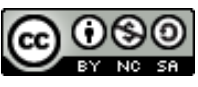

Saran

Diharapkan orang tua lebih memperhatikan pola makan balita, menjaga dan memenuhi asupan nutrisi terutama energi, zinc dan kalsium sesuai dengan kebutuhan balita.

\section{Daftar Pustaka}

Almatsier, S. (2004). Penuntun diet. Jakarta: PT Gramedia Pustaka Utama.

Almatsier, S. (2010). Prinsip dasar ilmu gizi, PT. Gramedia Pustaka Utama, Jakarta.

Anasiru, M. A., \& Domili, I. (2019). Pengaruh Asupan Energi dan Protein, Pola Asuh, dan Status Kesehatan Terhadap Kejadian Stunting pada Anak Usia 12-36 Bulan di Puskesmas Tilango Kecamatan Tilango Kabupaten Gorontalo.

Apriluana, G., \& Fikawati, S. (2018). Analisis Faktor-Faktor Risiko terhadap Kejadian Stunting pada Balita (0-59 Bulan) di Negara Berkembang dan Asia Tenggara. Media Penelitian Dan Pengembangan Kesehatan, 28(4), 247-256.

Astuti, S., Susanti, A. I., Nurparidah, R., \& Mandiri, A. (2017). Asuhan Ibu Dalam Masa Kehamilan. Jakarta: EGC.

Ayuningtyas, A., Simbolon, D., \& Rizal, A. (2018). Asupan Zat Gizi Makro dan Mikro terhadap Kejadian Stunting pada Balita. Jurnal Kesehatan, 9(3), 445-450.

sehari-hari. 
JURNAL ILMU KESEHATAN BHAKTI HUSADA:

HeAlth SCIENCES JoURNAL, Vol. 11 No. 02, DESEMBER 2020

DOI: $10.34305 / j i k b h . v 11 i 2.185$

Barasi, M. E. (2007). Nutritional principles. Nutrition at a Glance, 6-25.

Beriman, T., Hati, S., \& Hati, B. (2018). Pengaruh Pemberian Sari Kurma Pada Ibu Menyusui Ekslusif Terhadap Status Gizi Bayi Usia 0-5 Bulan Di Kota Semarang.

Bertalina, B., \& Amelia, P. R. (2018). Hubungan Asupan Gizi, Pemberian Asi Eksklusif, dan Pengetahuan Ibu dengan Status Gizi (Tb/U) Balita 6-59 Bulan. Jurnal Kesehatan, 9(1), 117125.

Chandra, A. (2013). Hubungan Underlyng Factors dengan Kejadian Stunting pada Anak 1-2 Tahun.e. Journal of Nutrition and Health., 1, 13-19.

Dinas Kesehatan Kota Cimahi. (2019). Rekapitulasi Penimbangan Balita Berdasarkan TB/U Tahun 2019. In Rekapitulasi Penimbangan Balita Berdasarkan TB/U Tahun 2019. Cimahi: Dinas Kesehatan Kota Cimahi. (Vol. 0, Issue 0). Poltekkes Kemenkes Pangkalpinang.

Endah, M. S., Mohammad, J., Neti, N., \& Mei Neni, S. (2019). Asupan protein, kalsium dan fosfor pada anak Stuntingdan tidak Stuntingusia 24-59 bulan. Jurnal Gizi Klinik Indonesia.

Fatmah, F. (2013). Intervensi biskuit tempe kurma bagi peningkatan status gizi balita penderita tuberkulosis. Jurnal Gizi Klinik Indonesia, 9(4), 147-154.

Hoq, M., Ali, M., Islam, A., \& Banerjee, C.
Ciptaan disebarluaskan di bawah

Lisensi Creative Commons Atribusi-

NonKomersial-BerbagiSerupa 4.0

Internasional.

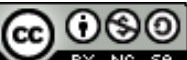

(9)

(2019). Risk factors of acute malnutrition among children aged 6 59 months enrolled in a communitybased programme in Kurigram, Bangladesh: a mixed-method matched case-control study. Journal of Health, Population and Nutrition, 38(1), 1-7.

Illahi, R. K. (2017). Hubungan pendapatan keluarga, berat lahir, dan panjang lahir dengan kejadian Stunting balita 24-59 bulan di Bangkalan. Jurnal Manajemen Kesehatan Yayasan RS. Dr. Soetomo, 3(1), 1-7.

Kementerian Kesehatan RI. (2020). Peraturan Menteri Kesehatan Republik Indonesia Nomor 2 Tahun 2020 Tentang Standar Antropometri Anak. Jakarta.

Kementrian Kesehatan, R. I. (2018). Riset Kesehatan Dasar (RISKESDAS) 2018. Jakarta: Badan Penelitian Dan Pengembangan Kesehatan. http://www.depkes.go.id/resources/do wnload/infoterkini/materi_rakorpop_2 018/Hasil Riskesdas 2018.pdf

Kementrian Kesehatan RI. (2018). Situasi Balita Pendek (Stunting) di Indonesia, Pusat Data dan Informasi Kementrian Kesehatan RI Semester I Tahun 2018. http://www.depkes.go.id/download.ph p?file=download/pusdatin/buletin/Bule tin-Stunting-2018.pdf

Maria C.L. (2010). Biokimia Nutrisi dan Metabolisme dengan Pemakaian secara Klinis. UI Press: Jakarta.

Marwat SK, Khan MA, Ahmad M, Zafar M, Khan MA, Fazal-ur-Rehman, S. S.

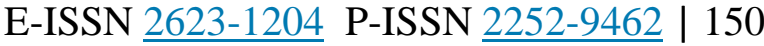


JURNAL ILMU KESEHATAN BHAKTI HUSADA:

HeAlth SCIENCES JoURNAL, Vol. 11 No. 02, DESEMBER 2020

DOI: $10.34305 / j i k b h . v 11 i 2.185$

(2009). Fruit plant species mentioned in the holy qura'n and ahadith and their ethnomedicinal importance. American Eurasian J. Agric. and Environ. Sci., 5(2)(84-95).

Suhardjo. (2007). Berbagai Cara Pendidikan Gizi. Jakarta: Bumi Aksara.

Surat Keputusan (SK) Gubernur Jawa Barat. (2019). Surat Keputusan (SK) Gubernur Jawa Barat Nomor 561/75/Yanbangsos tanggal 21 November 2019 tentang Pelaksanaan Upah Minimum Kabupaten/Kota di Daerah Provinsi Jawa Barat Tahun 2020.
Ciptaan disebarluaskan di bawah Lisensi Creative Commons Atribusi-

NonKomersial-BerbagiSerupa 4.0

Internasional.

Teguh A,. Susilowati, . Puji S. (2019). Hubungan Asupan Zat Gizi, Pola Asuh, Riwayat Penyakit Infeksi Dengan Kejadian Stunting Pada Balita (24-59 Bulan) Di Wilayah Puskesmas Cimahi Tengah Tahun 2019. Prosiding Seminar Keperawatan dan Workshop Stunting Series.

Trihono, T., Atmarita, A., Tjandrarini, D. H., Irawati, A., Nurlinawati, I., Utami, N. H., \& Tejayanti, T. (2015). Pendek (Stunting) di Indonesia, masalah dan solusinya. Lembaga Penerbit Badan Litbangkes

Wirjatmadi, B., \& Adriani, M. (2012). Pengantar gizi masyarakat. Jakarta: Kencana Prenada Media Group. 